\title{
Thiophene-Fused 1,10-Phenanthroline and Its Conjugated Polymers
}

Tingting Wang ${ }^{1,3}$, Hongyan Wang ${ }^{1,3}$, Guangwu $\mathrm{Li}^{2}$, Mengwei $\mathrm{Li}^{1,3}$, Zhishan $\mathrm{Bo}^{2}$, and Yulan Chen $^{1,3 *}$

1. Department of Chemistry, Tianjin University, Tianjin, 300072, P. R. China

2. Beijing Key Laboratory of Energy Conversion and Storage Materials, College of Chemistry, Beijing Normal University, Beijing, 100875, P. R.China

3. Collaborative Innovation Center of Chemical Science and Engineering (Tianjin)

*E-mail: yulan.chen@tju.edu.cn; zsbo@bnu.edu.cn

Phone/Fax: +86-22-27404118

\section{Materials and Methods}

General. Unless otherwise noted, all chemicals were purchased from Aldrich, Acros or Adamas and used without further purification. Dichloromethane $\left(\mathrm{CH}_{2} \mathrm{Cl}_{2}\right)$ was distilled over $\mathrm{CaH}_{2}$. Tetrahydrofuran (THF) was distilled over sodium and benzophenone. Other solvents were dried with standard procedures. All reactions were performed under an atmosphere of nitrogen and monitored by TLC with silica gel 60 F254. Column chromatography was carried out on silica gel (200-300 mesh). 
The catalyst precursor $\mathrm{Pd}\left(\mathrm{PPh}_{3}\right)_{4}$ was prepared according to the literature (S1), and stored in a Schlenk tube under nitrogen. 9,9-Dioctyl-2,7-diboronic ester-fluorene, 9,9-bis(6-bromohexyl)-2,7-diboronic ester-fluorene were prepared according to the literature procedures $(S 2, S 3)$. Britton-Robinson buffers with different $\mathrm{pH}$ values were prepared according to the literature procedure $(S 4)$.

Measurements. ${ }^{1} \mathrm{H}$ NMR (400 MHz) and ${ }^{13} \mathrm{C}$ NMR (100 MHz) spectra were recorded on a $400 \mathrm{MHz}$ Bruker $\mathrm{AV} 400$ spectrometer in $\mathrm{CDCl}_{3}$ or $d$-DMSO. Matrix assisted laser desorption ionization time-of-flight mass spectroscopy (MALDI-TOF) was performed on a Perseptive DE PRO Voyager MALDI-TOF mass spectrometer using $\alpha$-cyano-4-hydroxycinnamic acid as the matrix. The gel permeation chromatography (GPC) measurements were performed on PL-GPC 50 system against polystyrene standards with THF as an eluent. UV-vis absorption spectra were obtained on Shimadzu UV-vis model UV-1601 PC and PerkinElmer Lamda 750 spectrophotometers. Fluorescence spectra were recorded on a Hitachi F-7000 fluorescence spectrophotometer. TGA (PerkinElmer Pyris 1 TGA) and DSC (PerkinElmer DSC-8000) measurements were performed under a nitrogen atmosphere at a heating rate of $10{ }^{\circ} \mathrm{C} / \mathrm{min}$ to record the differential scanning calorimetry (DSC) and thermal gravimetric analysis (TGA), respectively. Cyclic voltammetric experiments were carried out using a $\mathrm{CHI} 660 \mathrm{E}$ electrochemical workstation $(\mathrm{CH}$ Instruments, ChenHua, Shanghai, China). All voltammograms were acquired at room temperature. A standard three electrode electrochemical cell arrangement was 
employed using a glassy carbon (GC) as working electrode, a Pt wire as counter electrode, and $\mathrm{Ag} / \mathrm{AgCl}$ as reference electrode in $0.1 \mathrm{M}$ tetrabutylammonium hexafluorophosphate $\left(\mathrm{TBAPF}_{6}\right)$ as the supporting electrolyte at the scan rate of 100 $\mathrm{mV} / \mathrm{s}$. The potentials are reported $v s$ the $\mathrm{Fc}^{+} / \mathrm{Fc}$ redox couple as a standard.

pH Sensing Experiment: $2 \mathrm{~mL}$ of Britton-Robinson buffer $(\mathrm{pH}=4-8)$ was taken into the cuvette, then $10 \mu \mathrm{L}$ of $\mathbf{P 3}$ solution $\left(2 \times 10^{-3} \mathrm{~mol} / \mathrm{L}\right.$ in methanol) was added to the buffer solution by a microinjector. As a very small amount of $\mathbf{P 3}$ solution was added, the final volume of the solution was nearly unchanged $(2 \mathrm{~mL})$. The mixed solutions were excited at $408 \mathrm{~nm}$ and the corresponding emission spectra were recorded.

Metal-ion Sensing Experiment: $2 \mathrm{~mL}$ of chloroform (for P1) or acetonitrile (for P3) was taken into the cuvette, then $10 \mu \mathrm{L}$ of polymer solution $\left(2 \times 10^{-3} \mathrm{~mol} / \mathrm{L}, \mathbf{P 1}\right.$ in chloroform or P3 methanol) and $40 \mu \mathrm{L}$ of different metal chloride solutions (0.05 $\mathrm{mol} / \mathrm{L}$ in methanol) were added to the polymer solution by a microinjector. As a very small amount of polymer and metal ion solutions were added, the final volume of the solution was nearly unchanged $(2 \mathrm{~mL})$. The mixed solution was excited at $406 \mathrm{~nm}$ (for P1) or $408 \mathrm{~nm}$ (for P3), and the corresponding emission spectra were recorded.

\section{Experimental Details.}

3,6-Dibromobenzene-1,2-diamine (2). 2 was synthesized according the literature procedure (S5): to a stirred solution of 4,7-dibromo-2,1,3-benzothiadiazole (5.0 $\mathrm{g}$, $17.0 \mathrm{mmol})$ in ethyl alcohol $(300 \mathrm{~mL})$ at $0{ }^{\circ} \mathrm{C}$ under $\mathrm{N}_{2}$ was added portion-wise sodium borohydride $(6.4 \mathrm{~g}, 170.1 \mathrm{mmol})$. After being stirred at $0{ }^{\circ} \mathrm{C}$ for $10 \mathrm{~min}$, the 
reaction mixture was stirred at room temperature for $3 \mathrm{~h}$. After being cooled to $0{ }^{\circ} \mathrm{C}$, the reaction mixture was treated with distilled water $(100 \mathrm{~mL})$. After removing the solvent under reduced pressure, the residue was diluted with ether $(200 \mathrm{~mL})$, washed with brine $(2 \times 200 \mathrm{~mL})$, dried over anhydrous $\mathrm{MgSO}_{4}$ and evaporated to dryness. The residue was purified by chromatography on silica gel column eluting with petroleum ether/ $\mathrm{CH}_{2} \mathrm{Cl}_{2}$ (v:v, 3:2) to afford 2 as a colorless solid $(4.0 \mathrm{~g}, 89 \%) .{ }^{1} \mathrm{H}$ NMR ( $\left.\mathrm{CDCl}_{3}, 400 \mathrm{MHz}\right): \delta 6.85(2 \mathrm{H}, \mathrm{s}, \mathrm{ArH}), 3.89\left(4 \mathrm{H}, \mathrm{s}, \mathrm{NH}_{2}\right)$.

N,N'-(3,6-Dibromo-1,2-phenylene)bis(2,2-dimethylpropanamide) (3). To a dry THF solution of $2(5.0 \mathrm{~g}, 18.9 \mathrm{mmol})$ and triethylamine $(3 \mathrm{~mL})$ was added dropwise a dry THF solution $(100 \mathrm{~mL})$ of pivaloyl chloride $(4.7 \mathrm{~g}, 38.8 \mathrm{mmol})$ at $0{ }^{\circ} \mathrm{C}$. After stirring at room temperature for $24 \mathrm{~h}$, the solution was poured into water $(100 \mathrm{~mL})$ and extracted with $\mathrm{CH}_{2} \mathrm{Cl}_{2}(2 \times 100 \mathrm{~mL})$. The combined organic extracts were dried over anhydrous $\mathrm{MgSO}_{4}$ and evaporated to dryness. The residue was purified by chromatography on silica gel column eluting with petroleum ether $/ \mathrm{CH}_{2} \mathrm{Cl}_{2}$ (v:v, 1:2) to afford 3 as a colorless solid $(7.1 \mathrm{~g}, 87 \%) .{ }^{1} \mathrm{H} \mathrm{NMR}\left(\mathrm{CDCl}_{3}, 400 \mathrm{MHz}\right): \delta 7.91(2 \mathrm{H}$, s, NH), $7.41(2 \mathrm{H}, \mathrm{s}, \mathrm{ArH}), 1.33\left(18 \mathrm{H}, \mathrm{s}, \mathrm{CH}_{3}\right) .{ }^{13} \mathrm{C} \mathrm{NMR}\left(\mathrm{CDCl}_{3}, 100 \mathrm{MHz}\right): \delta 177.13$, 133.21, 131.54, 121.09, 39.67, 27.60. MALDI-TOF, m/z: cacld, 434.0; found, 457.0 $\left([\mathrm{M}+\mathrm{Na}]^{+}\right)$

N,N'-(3,6-Di(thiophen-2-yl)-1,2-phenylene)bis(2,2-dimethylpropanamide) (4). A mixture of $\mathbf{3}$ (1.0 g, $2.3 \mathrm{mmol})$, thiophene-2-bronic ester (1.0 g, $4.7 \mathrm{mmol}), \mathrm{NaHCO}_{3}$ (9.8 g, $117 \mathrm{mmol})$, THF $(50 \mathrm{~mL})$ and $\mathrm{H}_{2} \mathrm{O}(20 \mathrm{~mL})$ was degassed before and after $\mathrm{Pd}\left(\mathrm{PPh}_{3}\right)_{4}(0.1 \mathrm{~g}, 0.09 \mathrm{mmol})$ was added. The mixture was heated to reflux and stirred 
under nitrogen for $24 \mathrm{~h}$. The reaction mixture was extracted with $\mathrm{CH}_{2} \mathrm{Cl}_{2}(3 \times 100$ $\mathrm{mL}$ ), and the combined organic layers were dried over anhydrous $\mathrm{MgSO}_{4}$ and evaporated to dryness. The residue was purified by chromatography on silica gel column eluting with petroleum ether/ $\mathrm{CH}_{2} \mathrm{Cl}_{2}(\mathrm{v}: \mathrm{v}, 2: 3)$ to afford $\mathbf{4}$ as an ivory solid $(0.7 \mathrm{~g}, 68 \%) .{ }^{1} \mathrm{H} \mathrm{NMR}\left(\mathrm{CDCl}_{3}, 400 \mathrm{MHz}\right): \delta 7.92(2 \mathrm{H}, \mathrm{s}, \mathrm{NH}), 7.41(2 \mathrm{H}, \mathrm{s}, \mathrm{ArH})$, $7.38(2 \mathrm{H}, \mathrm{dd}, \mathrm{ArH}), 7.15(2 \mathrm{H}, \mathrm{dd}, \mathrm{ArH}), 7.09(2 \mathrm{H}, \mathrm{m}, \mathrm{ArH}), 1.15\left(18 \mathrm{H}, \mathrm{s}, \mathrm{CH}_{3}\right) .{ }^{13} \mathrm{C}$ NMR $\left(\mathrm{CDCl}_{3}, 100 \mathrm{MHz}\right): \delta 177.12,139.50,132.04,131.13,128.83,127.24,126.98$, 126.33, 39.41, 27.50. MALDI-TOF, m/z: cacld, 440.1; found, $463.1\left([\mathrm{M}+\mathrm{Na}]^{+}\right)$.

4,7-Di-tert-butyldithieno[3,2-c:2',3'-i][1,10]phenanthroline (5). A solution of 4 (0.5 $\mathrm{g}, 1.1 \mathrm{mmol}), \mathrm{P}_{2} \mathrm{O}_{5}(3.2 \mathrm{~g}, 22.7 \mathrm{mmol})$ and $\mathrm{POCl}_{3}(15 \mathrm{~mL})$ was stirred at reflux for 30 h under $\mathrm{N}_{2}$. The mixture was concentrated under vacuum, the residue was diluted with dichloromethane $(50 \mathrm{~mL})$, and water $(50 \mathrm{~mL})$ was added slowly. The aqueous layer was adjusted to $\mathrm{pH}=10$ with $\mathrm{KOH}$ solution $(5 \mathrm{M})$ and extracted with dichloromethane $(2 \times 15 \mathrm{~mL})$. The combined organic layers were dried over anhydrous $\mathrm{MgSO}_{4}$ and evaporated to dryness. The product was purified by chromatography on alkaline $\mathrm{Al}_{2} \mathrm{O}_{3}$ column eluting with $\mathrm{CH}_{2} \mathrm{Cl}_{2}$ and the residue was recrystallized in $\mathrm{CH}_{2} \mathrm{Cl}_{2}$ /petroleum ether to afford $\mathbf{5}$ as a slightly brown solid ( $0.18 \mathrm{~g}$, 40\%). ${ }^{1} \mathrm{H}$ NMR $\left(\mathrm{CDCl}_{3}, 400 \mathrm{MHz}\right): \delta 8.18$ (s, 2H, ArH), 7.99 (2H, d, ArH), $7.62(2 \mathrm{H}$, d, $\mathrm{ArH}), 1.79\left(18 \mathrm{H}, \mathrm{s}, \mathrm{CH}_{3}\right) .{ }^{13} \mathrm{C} \mathrm{NMR}\left(\mathrm{CDCl}_{3}, 100 \mathrm{MHz}\right): \delta 164.38,147.23,139.87$, 131.59, 125.60, 125.30, 123.04, 122.12, 40.58, 30.10. MALDI-TOF, m/z: cacld, 404.1; found, $405.1\left([\mathrm{M}+\mathrm{H}]^{+}\right)$.

2,9-Dibromo-4,7-di-tert-butyldithieno[3,2-c:2',3'-i][1,10]phenanthroline (6). To a 
solution of diisopropylamine $(1.4 \mathrm{~g}, 14.2 \mathrm{mmol})$ in THF $(50 \mathrm{~mL})$ cooled to $-50{ }^{\circ} \mathrm{C}$ was added $n$-butyllithium (10.9 mmol, $2.5 \mathrm{M}$ in hexane) and the resulting solution was stirred at $-50{ }^{\circ} \mathrm{C}$ for $0.5 \mathrm{~h}$. The mixture was added into the THF solution of 5 ( $1 \mathrm{~g}, 2.5$ mmol) at $-50{ }^{\circ} \mathrm{C}$ and stirred for $45 \mathrm{~min}$, then added the THF solution of $\mathrm{CBr}_{4}(4.7 \mathrm{~g}$, $14.2 \mathrm{mmol}$ ) at $-50{ }^{\circ} \mathrm{C}$ and stirred for $24 \mathrm{~h}$. The reaction mixture was extracted with $\mathrm{CH}_{2} \mathrm{Cl}_{2}(3 \times 50 \mathrm{~mL})$, and the combined organic layers were dried over anhydrous $\mathrm{MgSO}_{4}$ and evaporated to dryness. The product was purified by chromatography on alkaline $\mathrm{Al}_{2} \mathrm{O}_{3}$ column eluting with $\mathrm{CH}_{2} \mathrm{Cl}_{2}$ and the residue was recrystallized in $\mathrm{CH}_{2} \mathrm{Cl}_{2}$ / petroleum ether to afford a slight brown solid $(0.84 \mathrm{~g}, 60 \%) .{ }^{1} \mathrm{H}$ NMR $\left(\mathrm{CDCl}_{3}, 400 \mathrm{MHz}\right): \delta 7.98(2 \mathrm{H}, \mathrm{s}, \mathrm{ArH}), 7.95(2 \mathrm{H}, \mathrm{s}, \mathrm{ArH}), 1.75\left(18 \mathrm{H}, \mathrm{s}, \mathrm{CH}_{3}\right) .{ }^{13} \mathrm{C}$ NMR $\left(\mathrm{CDCl}_{3}, 100 \mathrm{MHz}\right): \delta 163.38,148.26,139.74,131.78,128.27,121.99,121.93$, 114.57, 40.54, 30.02. MALDI-TOF, m/z: cacld, 561.9; found, $562.9\left([\mathrm{M}+\mathrm{H}]^{+}\right)$.

Polymer P1. A mixture of $\quad \begin{array}{llllll} & \text { A } & (50.0 & \mathrm{mg}, & 88.9 & \mu \mathrm{mol}) \text {, }\end{array}$ 2,2'-(9,9-dioctyl-9H-fluorene-2,7-diyl)bis(4,4,5,5-tetramethyl-1,3,2-dioxaborolane)

(58.7 mg, $94.2 \mu \mathrm{mol}), \mathrm{NaHCO}_{3}(284.5 \mathrm{mg}, 3.4 \mathrm{mmol}), \mathrm{THF}(5 \mathrm{~mL})$, toluene $(1 \mathrm{~mL})$ and $\mathrm{H}_{2} \mathrm{O}(1 \mathrm{~mL})$ was carefully degassed before and after $\mathrm{Pd}\left(\mathrm{PPh}_{3}\right)_{4}(2 \mathrm{mg}, 1.7 \mu \mathrm{mol})$ was added. The mixture was heated to reflux and stirred under nitrogen for $96 \mathrm{~h}$. The reaction mixture was extracted with $\mathrm{CHCl}_{3}(3 \times 30 \mathrm{~mL})$, and combined organic layers were dried over anhydrous $\mathrm{MgSO}_{4}$. After the removal of most of solvent, the residue was precipitated into methanol. The resulted precipitate was collected by filtration and dried under vacuum to give $\mathbf{P 1}$ as a green-yellow solid (60 mg, 90\%). ${ }^{1} \mathrm{H}$ NMR $\left(\mathrm{CDCl}_{3}, 400 \mathrm{MHz}\right): \delta 8.22(4 \mathrm{H}$, broad $), 7.86-7.75(6 \mathrm{H}$, broad $), 2.22-1.88(22 \mathrm{H}, \mathrm{m})$, 
1.14 (24H, broad), 0.79 (6H, broad). $\left.{ }^{13} \mathrm{C} \mathrm{NMR} \mathrm{(} \mathrm{CDCl}_{3}, 100 \mathrm{MHz}\right): \delta 164.21,152.51$, $151.20,150.27,146.61,144.35,141.18,139.90,133.04,132.81,129.93,128.88$, $125.86,125.53,122.85,122.18,120.95,120.65,55.69,55.44,49.90,40.66,31.88$, $30.26,30.12,29.96,29.76,29.36,29.22,27.23,24.98,23.86,22.61,14.11$.

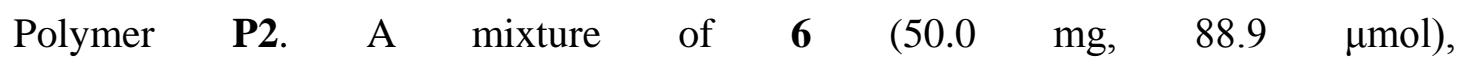
2,2'-(9,9-bis(6-bromohexyl)-9H-fluorene-2,7-diyl)bis(4,4,5,5-tetramethyl-1,3,2-dioxa bo-rolane) $(67.2 \mathrm{mg}, 91.4 \mu \mathrm{mol}), \mathrm{NaHCO}_{3}(284.5 \mathrm{mg}, 3.4 \mathrm{mmol})$, THF $(5 \mathrm{~mL})$, toluene $(1 \mathrm{~mL})$ and $\mathrm{H}_{2} \mathrm{O}(1 \mathrm{~mL})$ was carefully degassed before and after $\mathrm{Pd}\left(\mathrm{PPh}_{3}\right)_{4}(2$ $\mathrm{mg}, 1.7 \mu \mathrm{mol})$ was added. The mixture was heated to reflux and stirred under nitrogen for $96 \mathrm{~h}$. The reaction mixture was extracted with $\mathrm{CHCl}_{3}(3 \times 30 \mathrm{~mL})$, and combined organic layers were dried over anhydrous $\mathrm{MgSO}_{4}$. After the removal of most of solvent, the residue was precipitated into methanol. The resulted precipitate was collected by filtration and dried under vacuum to give $\mathbf{P 2}(66 \mathrm{mg}, 88 \%)$ as a dark green solid. ${ }^{1} \mathrm{H} \mathrm{NMR}\left(\mathrm{CDCl}_{3}, 400 \mathrm{MHz}\right): \delta 8.23-8.20(4 \mathrm{H}$, broad), 7.88-7.79 $(6 \mathrm{H}$, broad), $3.29(4 \mathrm{H}, \mathrm{m}), 2.22-1.71(26 \mathrm{H}, \mathrm{m}), 1.25-1.13(12 \mathrm{H}$, broad $) .{ }^{13} \mathrm{C} \mathrm{NMR}\left(\mathrm{CDCl}_{3}\right.$, $100 \mathrm{MHz}): \delta 164.24,151.82,146.60,144.19,141.10,139.88,132.79,125.99,122.82$, $122.18,120.76,55.57,40.66,33.98,32.60,30.26,29.71,29.04,27.80,24.99,23.68$.

Polymer P3. Trimethylamine ( $1 \mathrm{~mL}, 20 \% \mathrm{wt})$ was added dropwise to a solution of the neutral precursor polymer $2(25 \mathrm{mg}, 0.028 \mu \mathrm{mol})$ in $\mathrm{THF}(5 \mathrm{~mL})$ at $-78{ }^{\circ} \mathrm{C}$ under $\mathrm{N}_{2}$. The mixture was allowed to warm up to room temperature and the precipitate was redissolved by addition of water $(10 \mathrm{~mL})$. After the mixture was cooled down to -78 ${ }^{\circ} \mathrm{C}$, extra trimethylamine $(1 \mathrm{~mL}, 20 \% \mathrm{wt})$ was added and the mixture was stirred for 
$24 \mathrm{~h}$ at room temperature. The green product was collected after removing the solvent (25 mg, 90\%). ${ }^{1} \mathrm{H}$ NMR ( $d$-DMSO, 353K, $400 \mathrm{MHz}$ ): $\delta$ 8.49-8.37 (4H, m), 8.24-7.98 (6H, m), 2.98-2.94 (22H, m), 1.84-1.68 (22H, m), 1.52-1.15 (16H, m).

\section{Supporting Figures.}
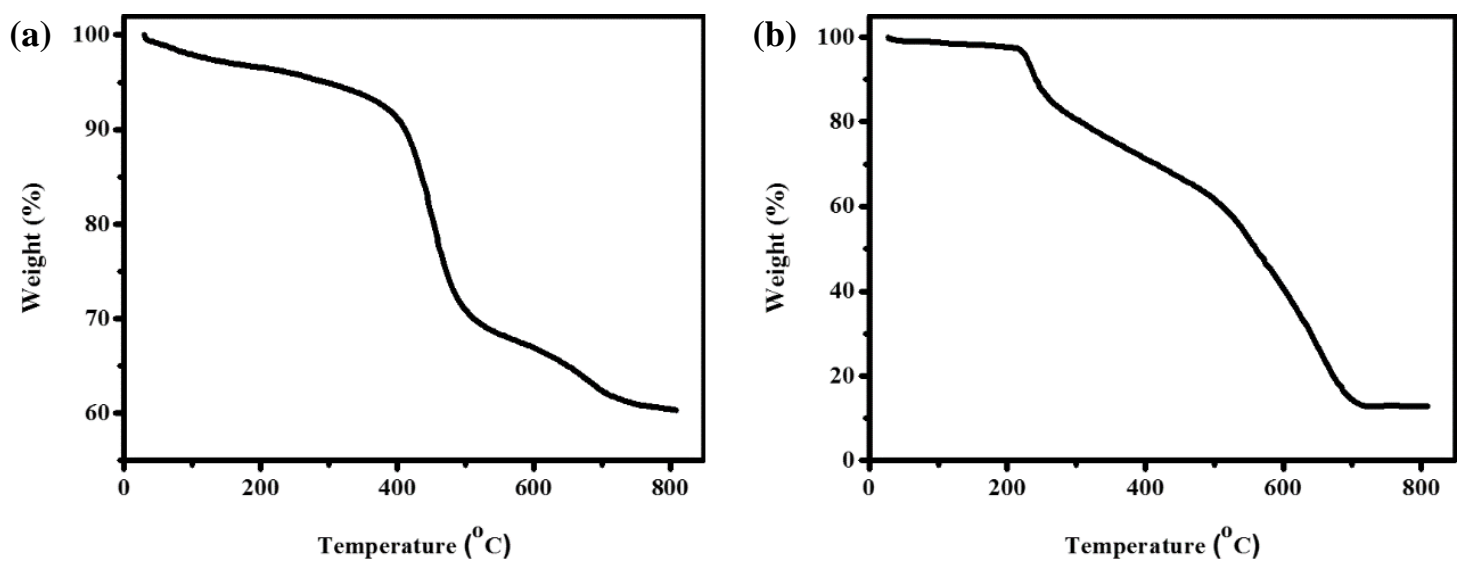

Figure S1. TGA traces of (a) P1 and (b) P2.

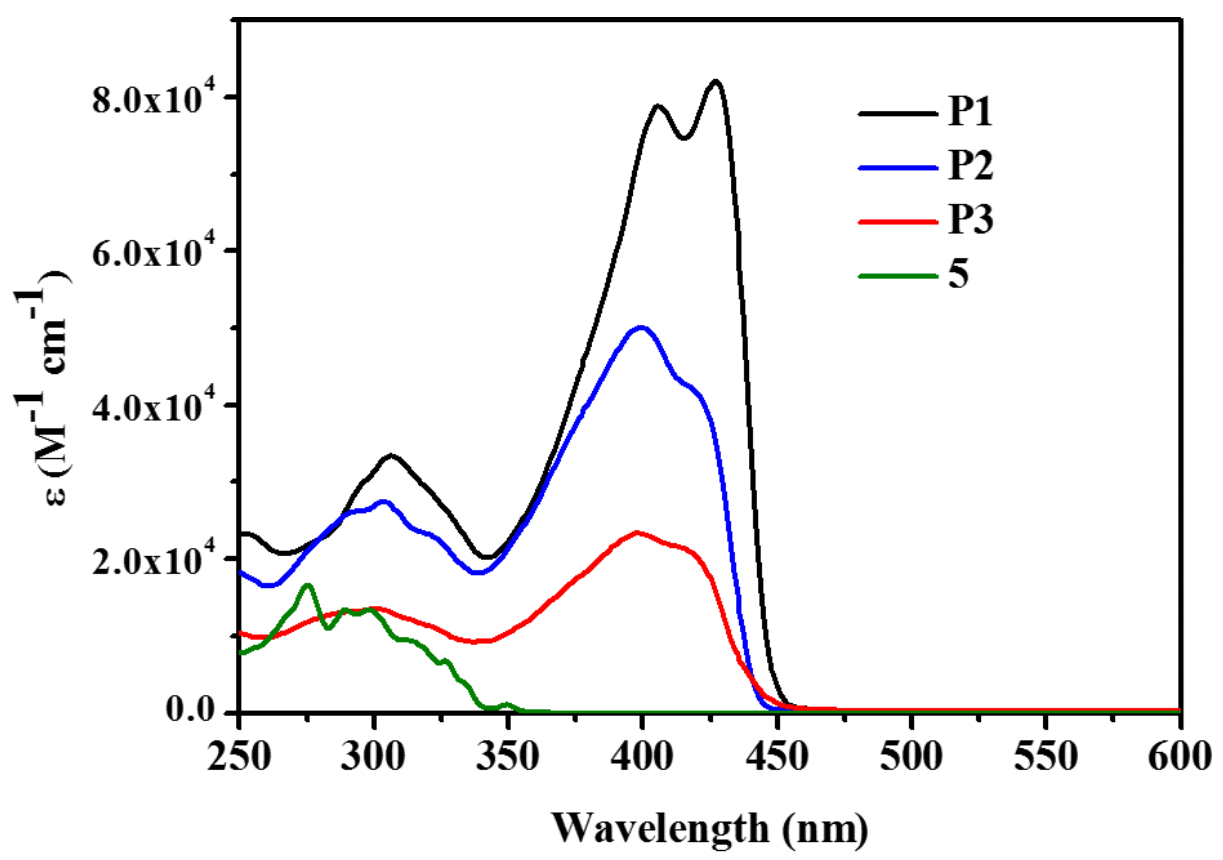

Figure S2. UV-vis absorption spectra of 5, P1 and $\mathbf{P 2}$ in chloroform, and $\mathbf{P 3}$ in methanol. 

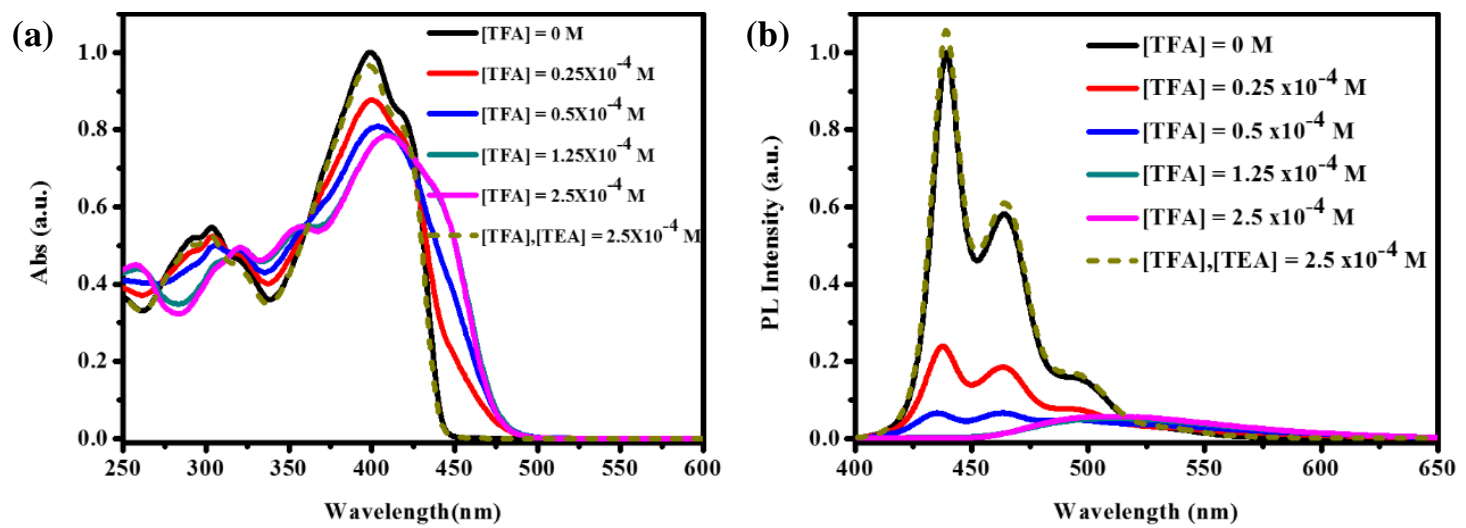

(c)
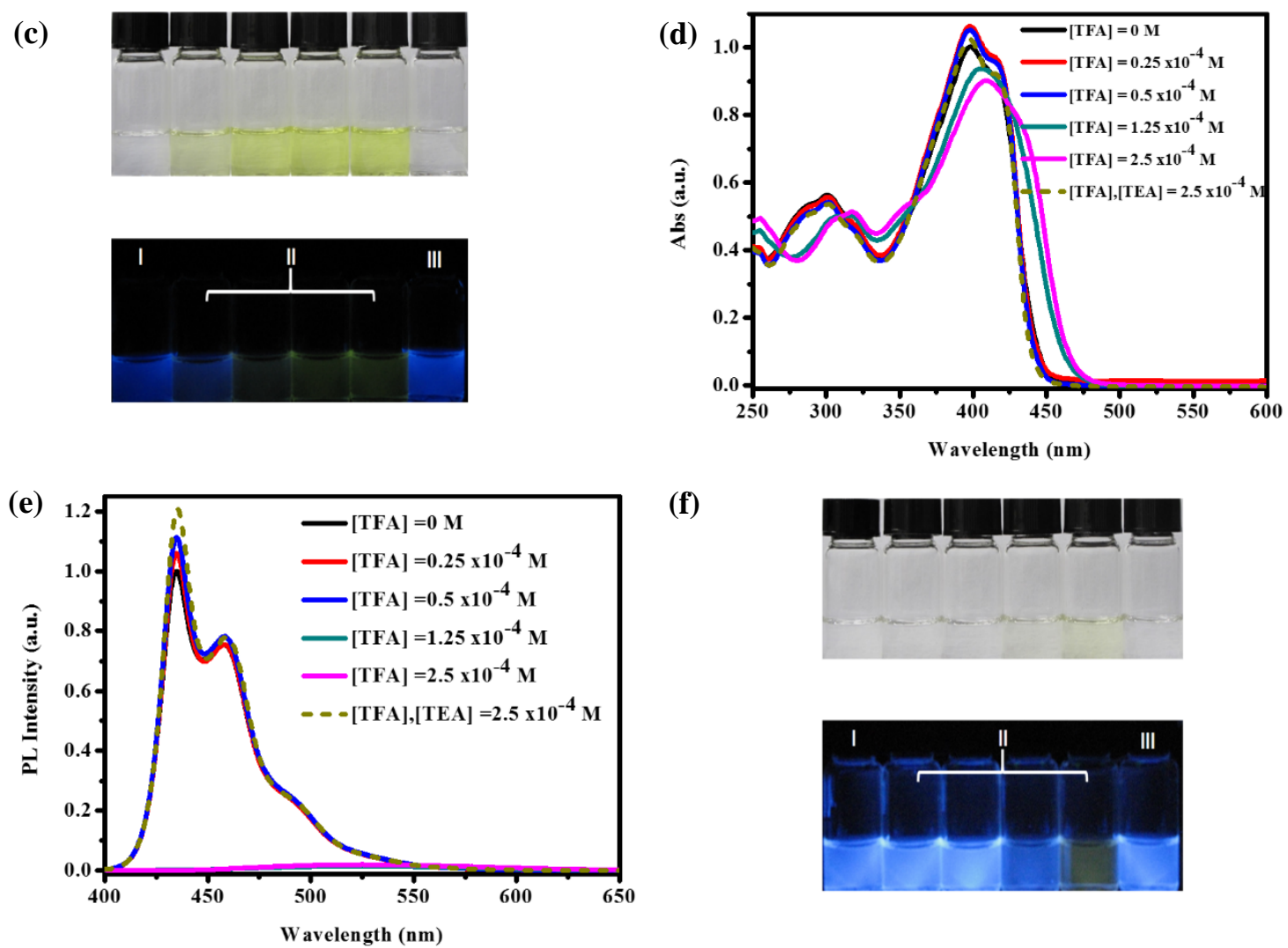

(f)
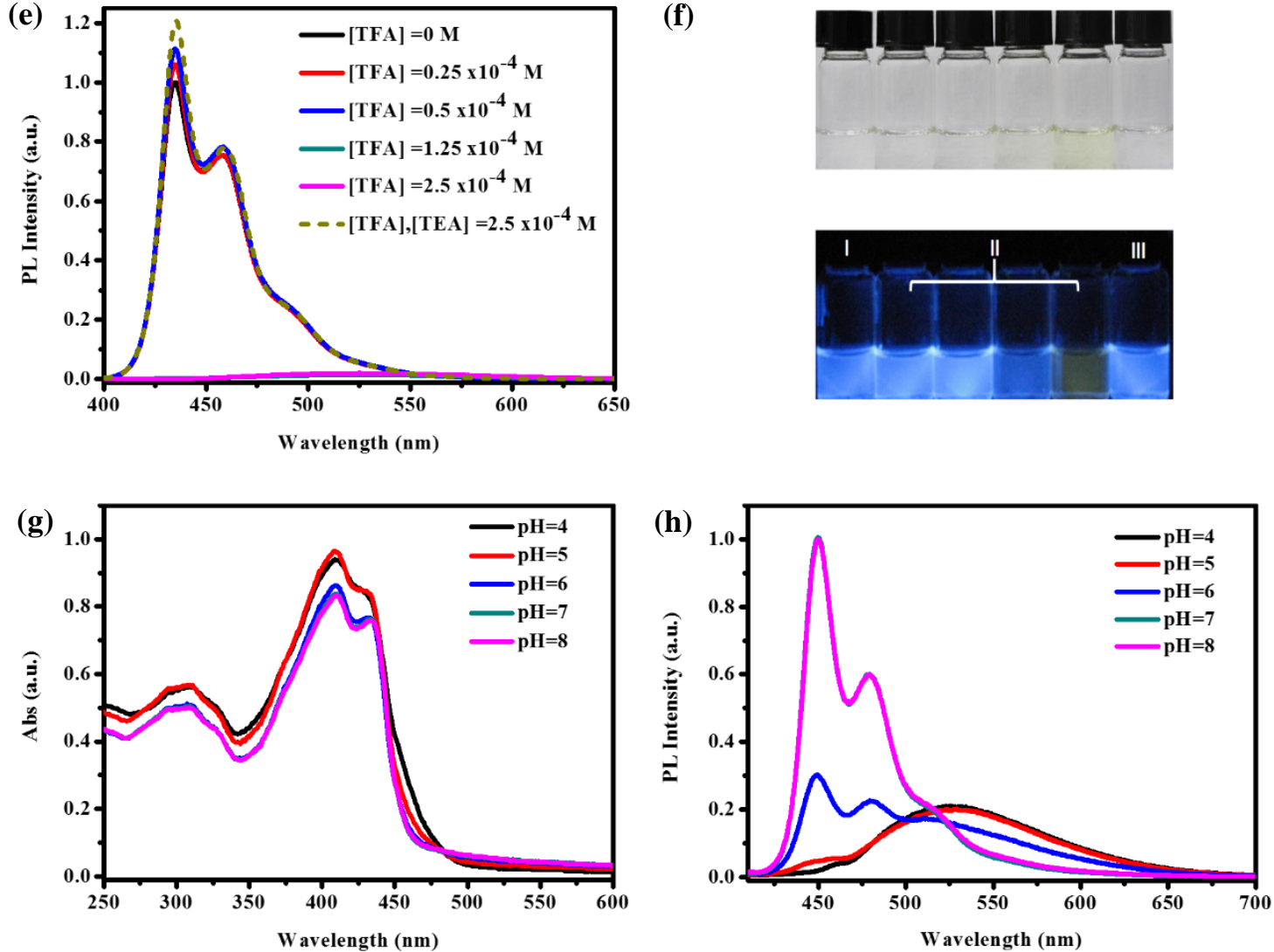

Figure S3. (a), (d), (g) UV-vis absorption and (b), (e), (h) PL spectra of P2 (a, b) in chloroform, P3

$(\mathrm{d}, \mathrm{e})$ in methanol at various concentrations of TFA, and P3 $(\mathrm{g}, \mathrm{h})$ in Britton-Robinson buffer with 
different $\mathrm{pH}\left(10^{-5} \mathrm{M}\right.$ for repeating unit). Dash lines represent the recovery of the optical properties when the protonated polymer solution was treated with TEA; Pictures of (c) P2 in chloroform, (f) $\mathbf{P 3}$ in methanol (I) before and (II) after the titration of TFA, and (III) the recovery of optical property after treated with TEA (taken under nature light and under the illumination with $365 \mathrm{~nm}$ UV light).

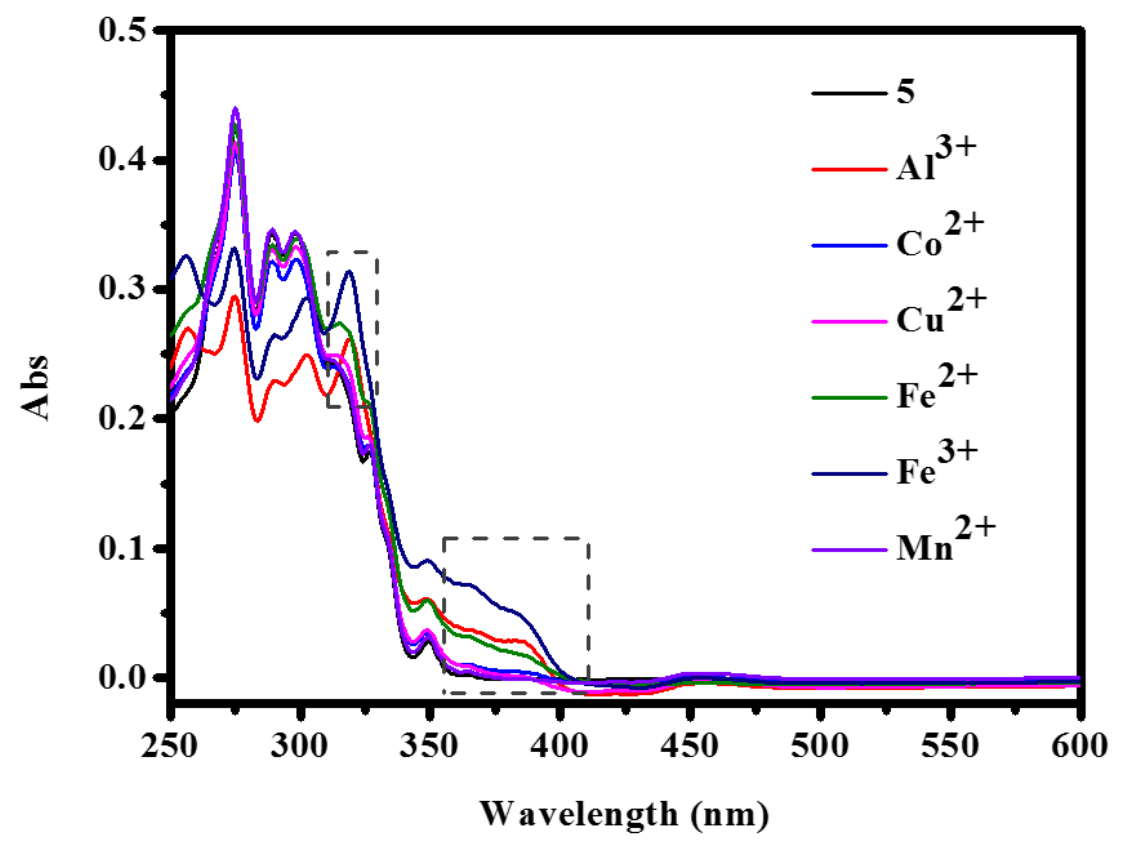

Figure S4. UV-vis absorption spectra of $\mathbf{5}$ in chloroform after the addition of methanol solutions of metal chlorides $\left([5],\left[\mathrm{M}^{\mathrm{n}+}\right]=10^{-5} \mathrm{M}\right)$.
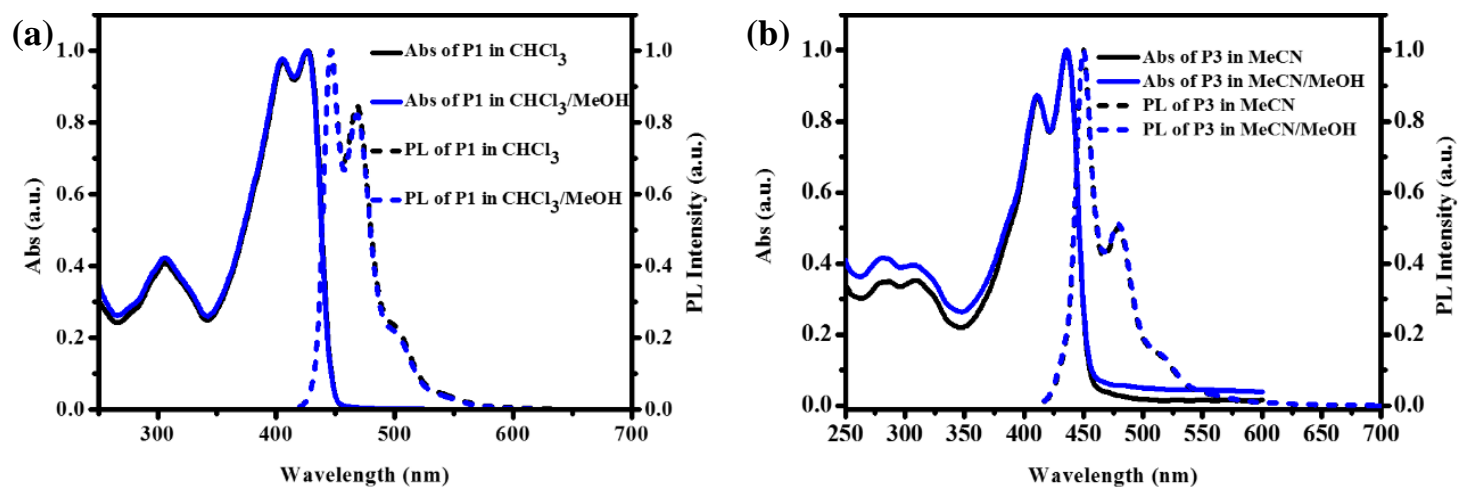

Figure S5. Control experiments with the addition of methanol to the polymer solutions showed no 
changes of their optical properties: UV-vis absorption and PL spectra of (a) P1 in chloroform, and (b) $\mathbf{P} 3$ in acetonitrile with and without methanol (3 vol\%) $\left(10^{-5} \mathrm{M}\right.$ for repeating unit).
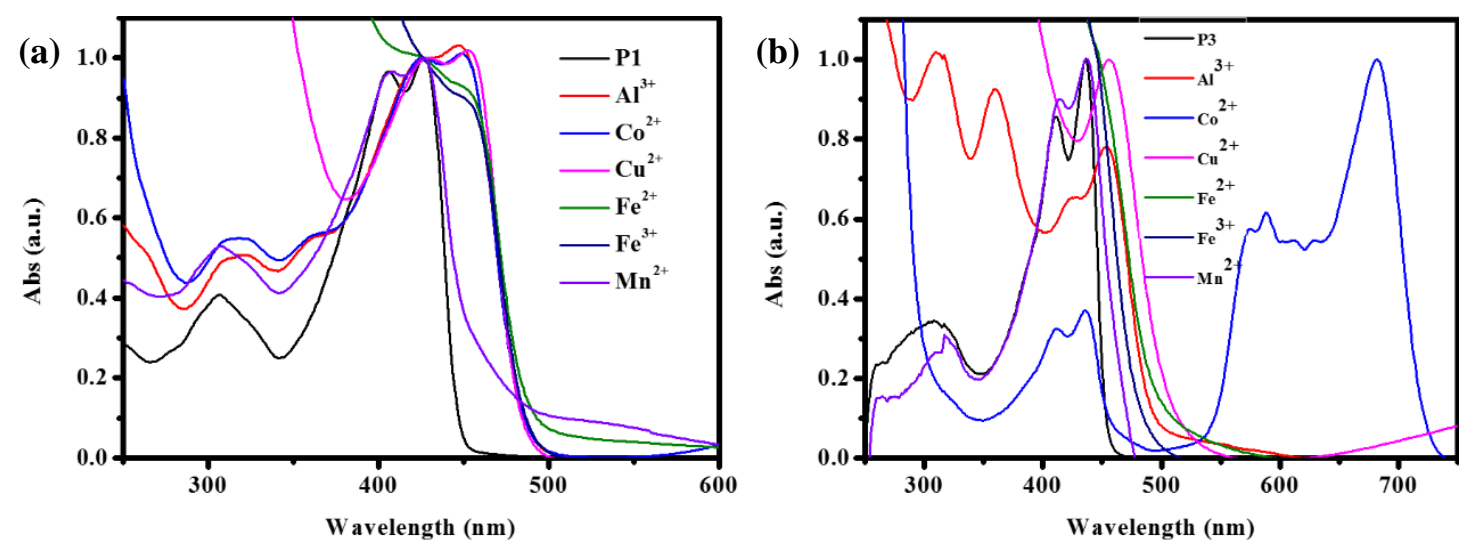

Figure S6. UV-vis absorption spectra of (a) $\mathbf{P 1}$ in chloroform and (b) $\mathbf{P 3}$ in acetonitrile (10 $0^{-5} \mathrm{M}$ for repeating unit) to metal chlorides $\left(10^{-3} \mathrm{M}\right)$.

(a)
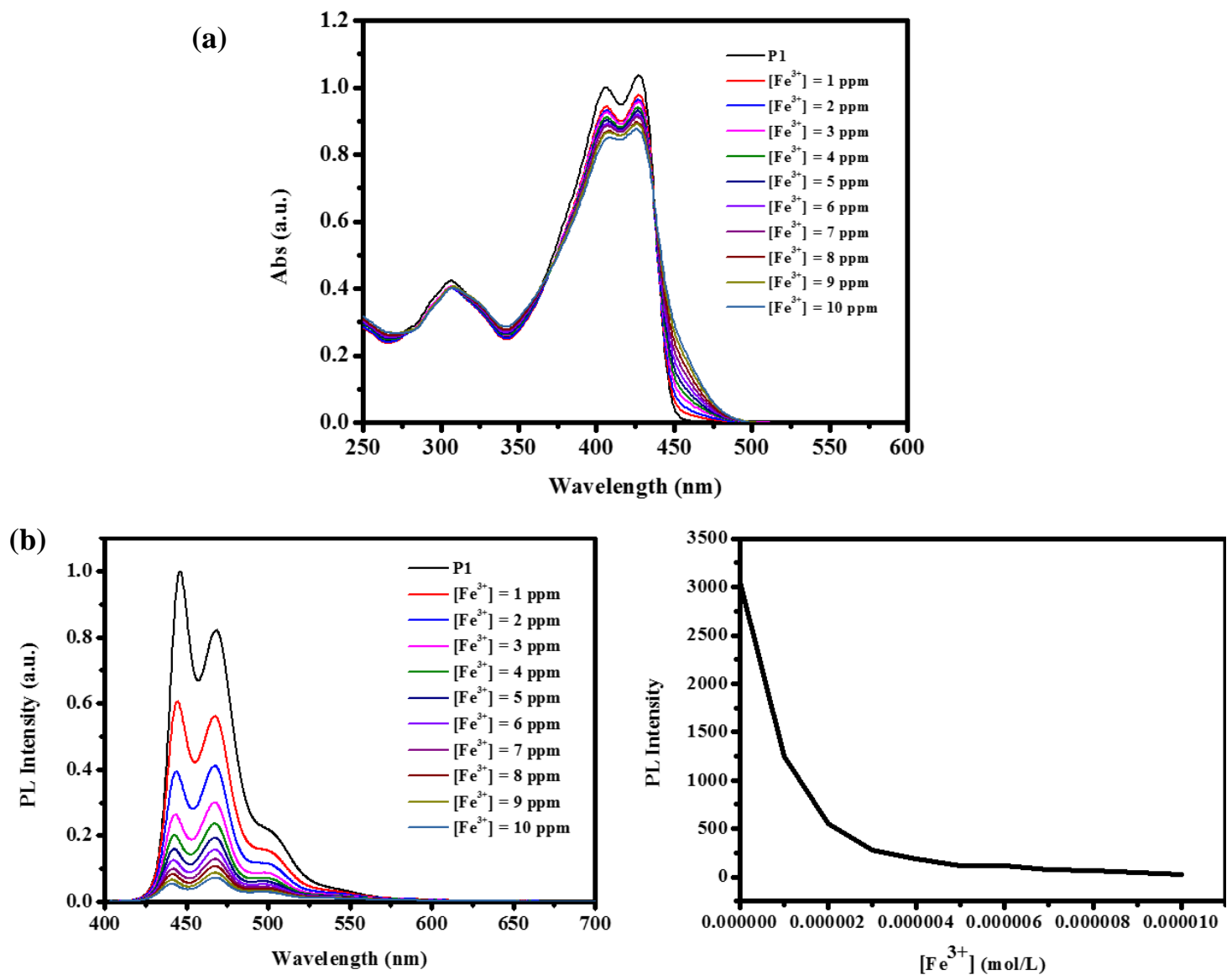
Figure S7. (a) UV-vis absorption spectra and (b) fluorescence quenching of $\mathbf{P 1}$ in chloroform $\left(10^{-5}\right.$ $\mathrm{M}$ for repeating unit) in the presence of $\mathrm{Fe}^{3+}$.

Crystal Data of 6 (CCDC 1450922).

\begin{tabular}{|c|c|}
\hline Empirical formula & $\mathrm{C} 24 \mathrm{H} 22 \mathrm{Br} 2 \mathrm{~N} 2 \mathrm{~S} 2$ \\
\hline Space group & P 21/c \\
\hline Cell lengths & $\mathrm{a} / \AA ̊ \mathrm{~A} 6.25656(20) \quad \mathrm{b} / \AA \AA^{2} 2.1295(8) \quad \mathrm{c} / \AA \AA^{17}$ 17.8928(6) \\
\hline Cell angels & $\alpha /^{\circ} 90.00 \beta / /^{\circ} 96.663(3) \gamma /{ }^{\circ} 90.00$ \\
\hline Cell volume & $2238.22 / \AA^{3}$ \\
\hline $\mathbf{Z}, \mathbf{Z}$ & Z: $4 \quad$ Z': 0 \\
\hline R-Factor $(\%)$ & 3.44 \\
\hline
\end{tabular}

${ }^{1}$ H NMR spectra. 


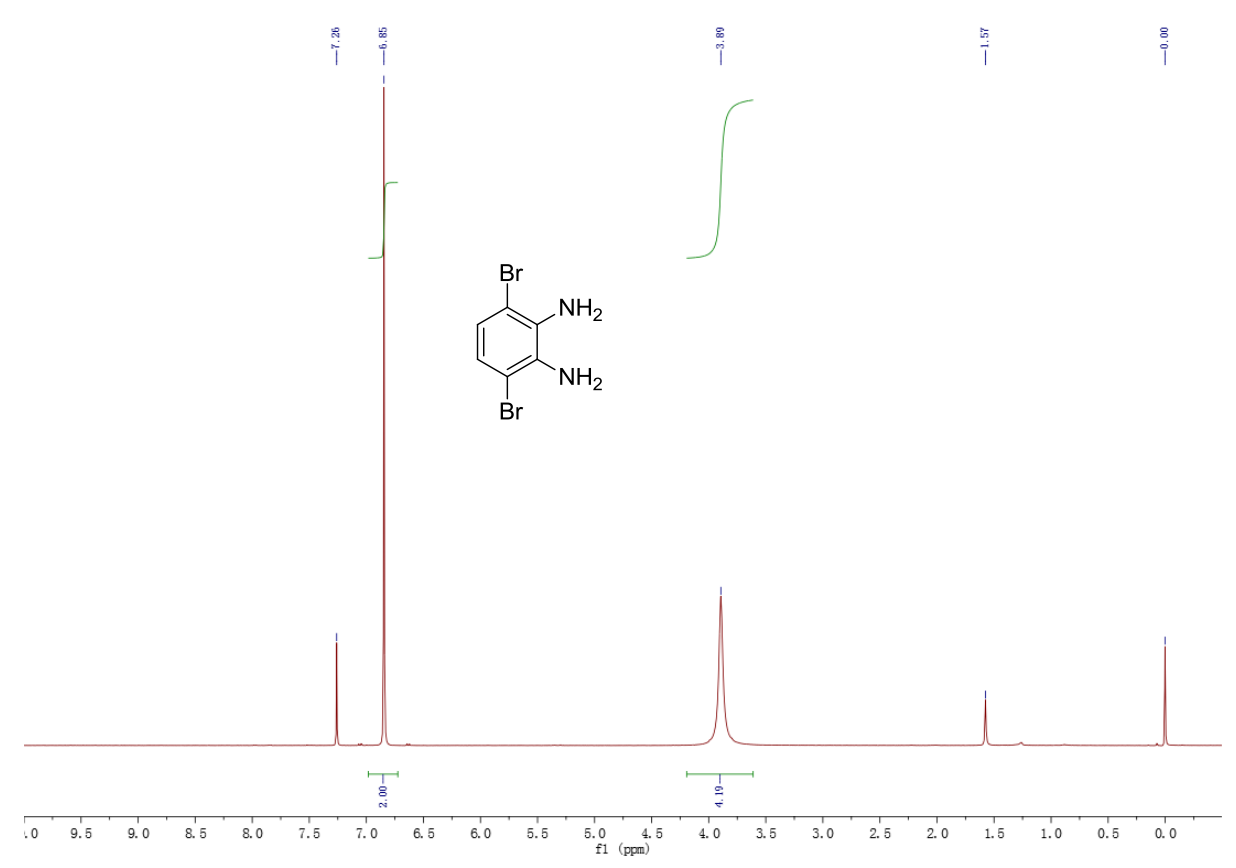

Tิ

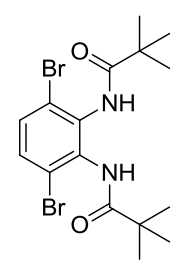

3

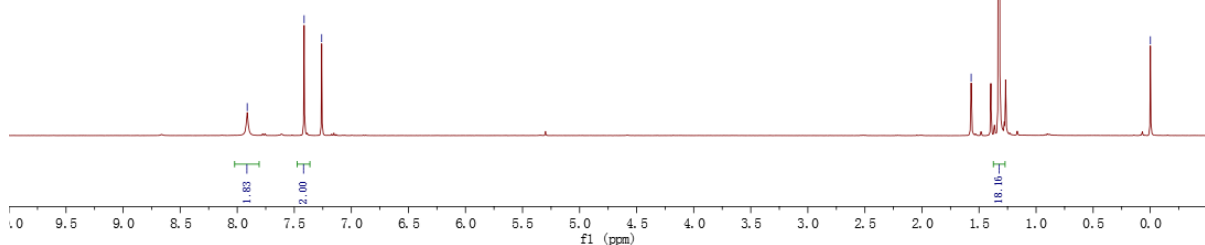




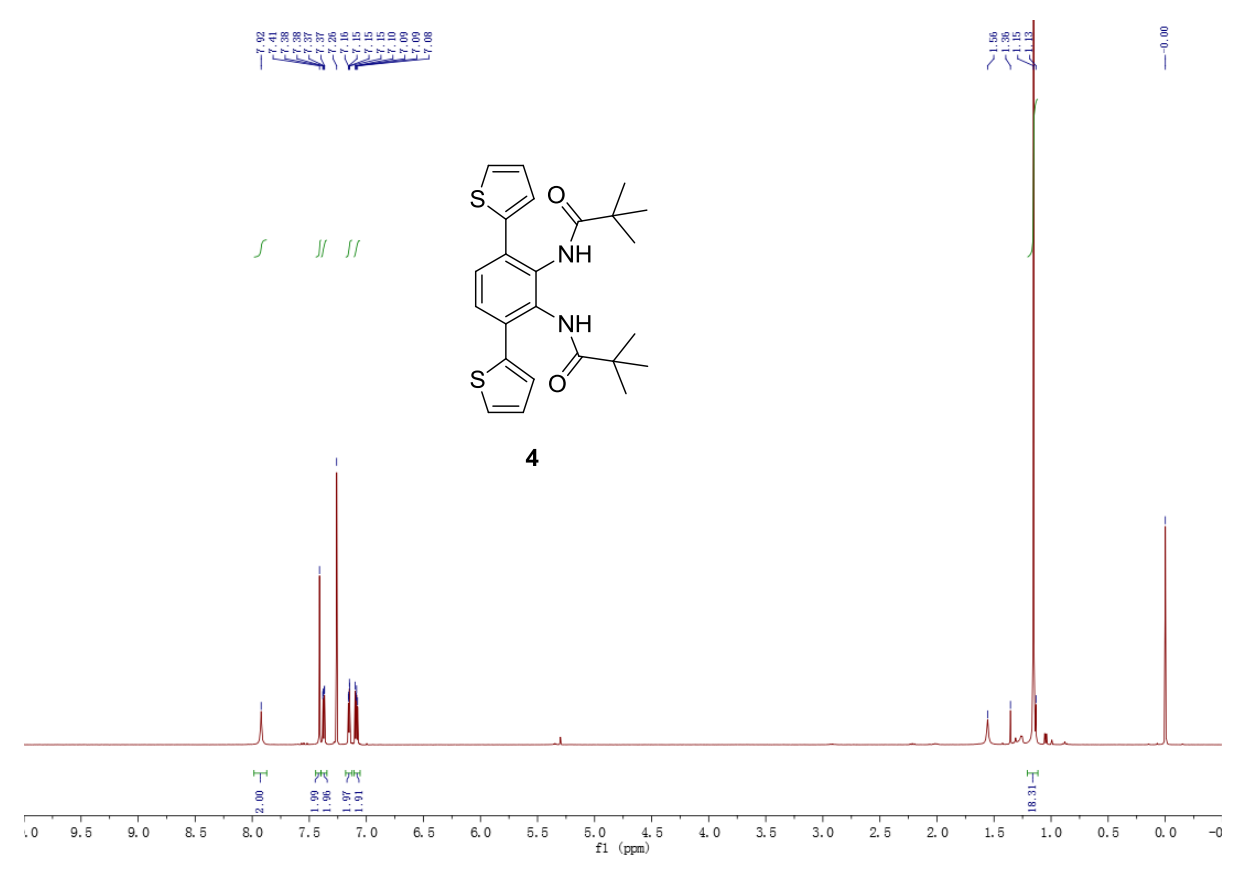

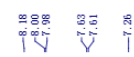
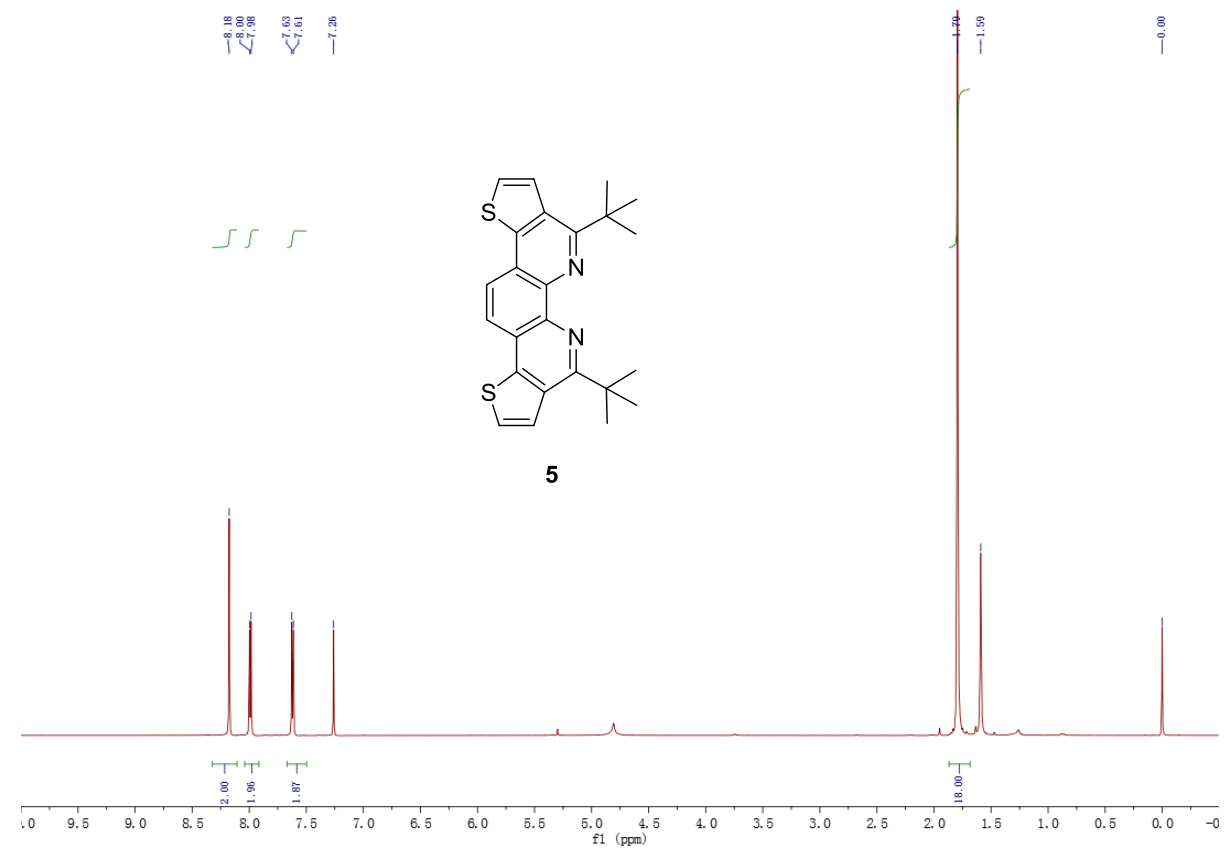

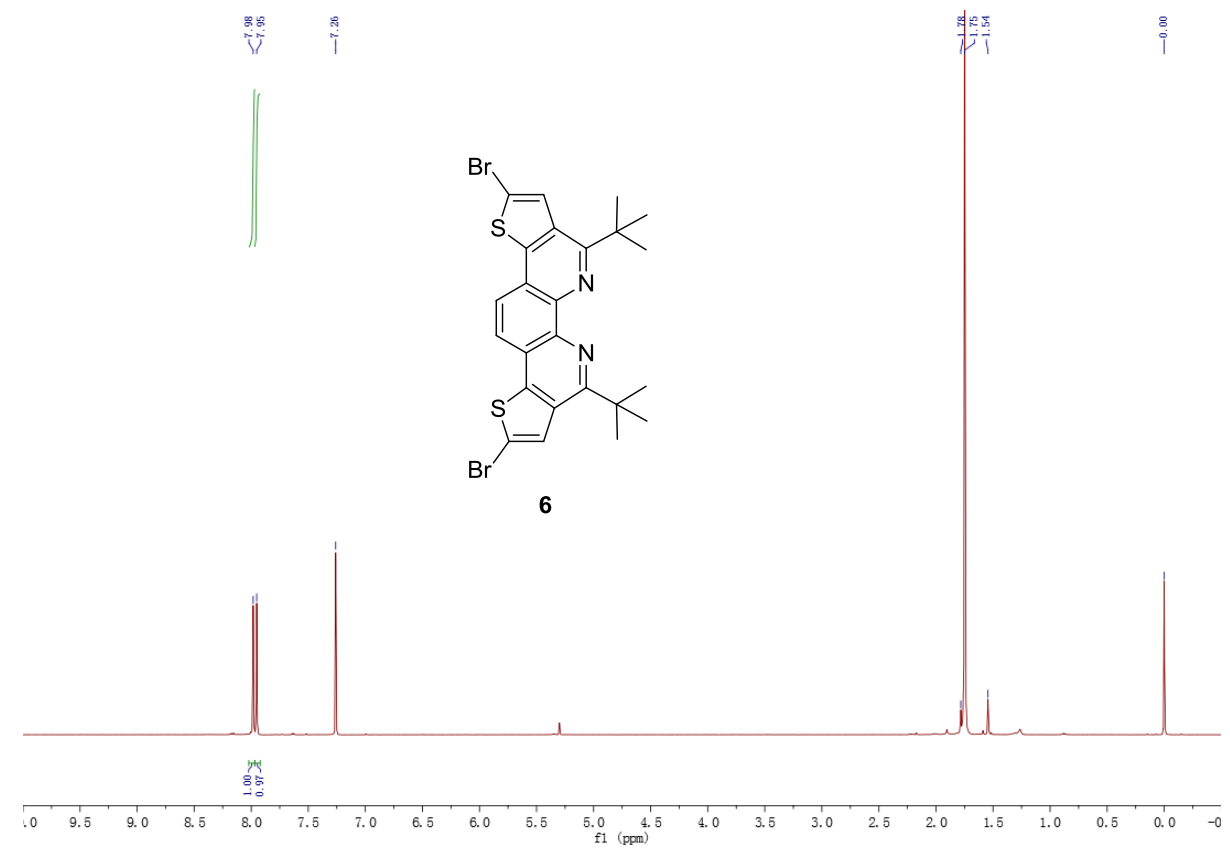

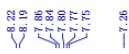

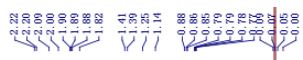
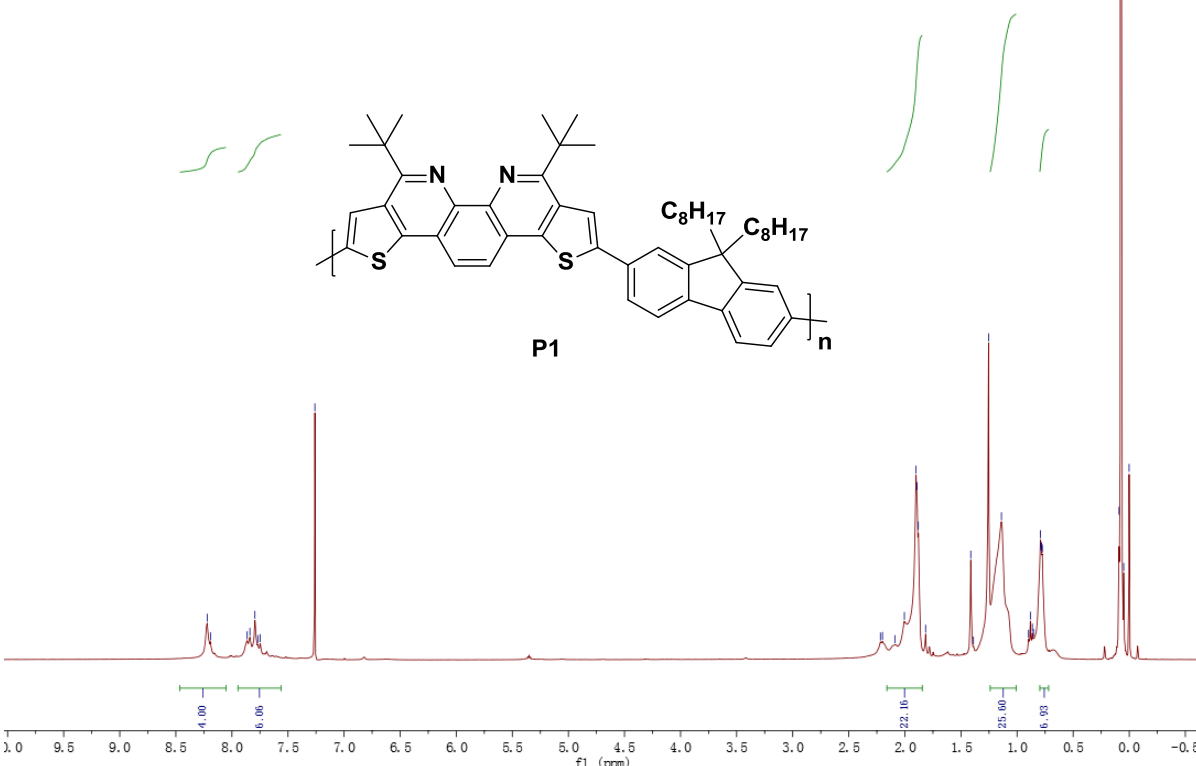

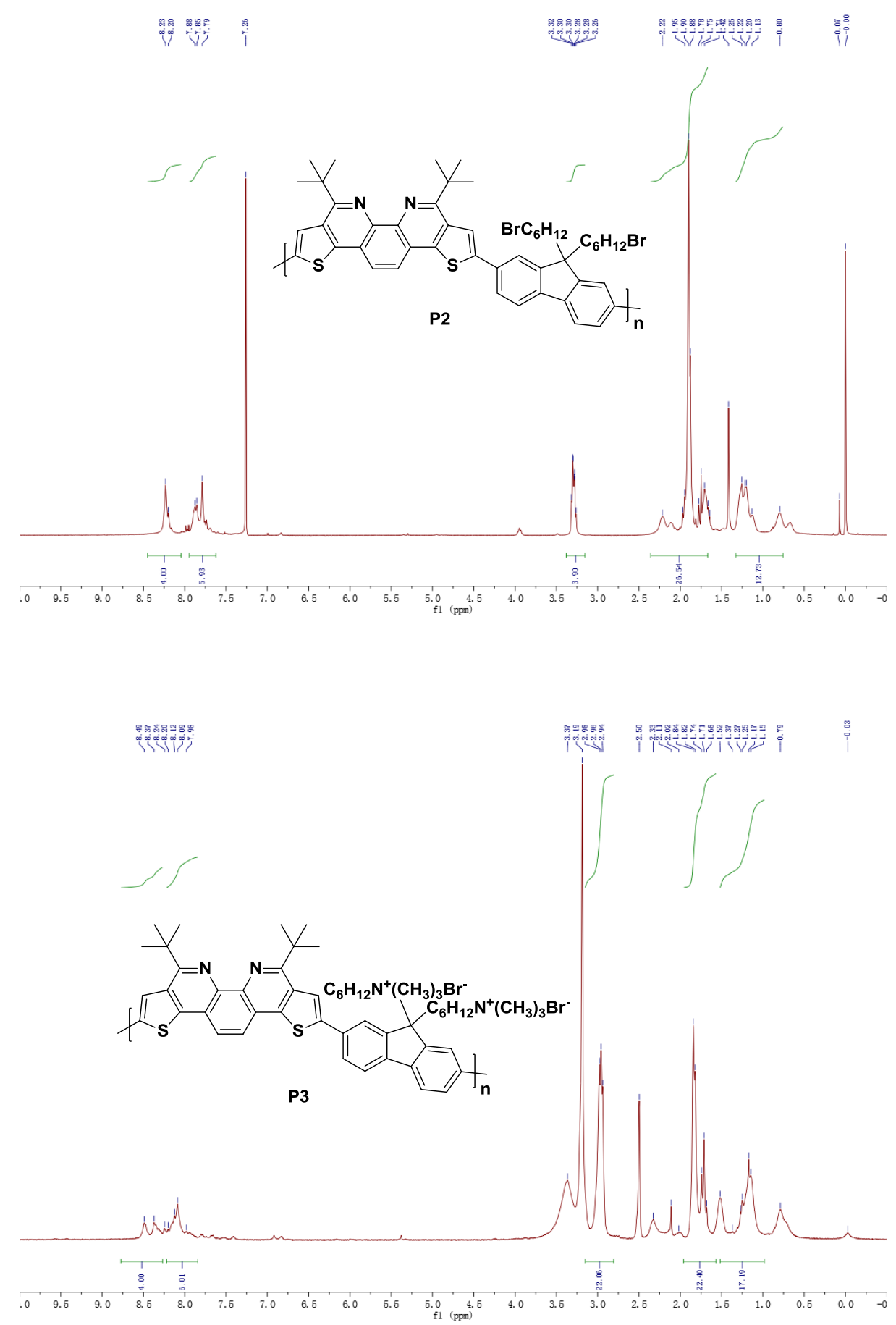

\section{References.}

S1. Tolman, C. A.; Seidel, W. C.; Gerlach, D. H. J. Am. Chem. Soc. 1972, 94, 2669.

S2. Chen, H.; He, M. Y.; Pei, J.; Liu, B. Anal. Chem. 2002, 74, 6252.

S3. Lee, W.-H.; Mohanty, A. D.; Bae, C. ACS Macro Lett. 2015, 4, 453. 
S4. Britton, H. T. S.; Robinson, R. A. J. Chem. Soc. 1931, 1456.

S5. Kim, J.; Park, S.-H.; Kim J.; Cho, S.; Jin, Y.; Shim, J.-Y.; Shin, H.; Kwon, S.; Kim, I.; Lee, K.; J. H., A.; Suh, H. J. Polym. Sci., Part A: Polym. Chem. 2011, 49, 369. 